\title{
THE COMMUNICATIVE MODE OF MENTATIVE
}

\author{
Margarita Zaitseva \\ Ph.D., Assistant Professor, Yaroslav Mudryi National Law University, Ukraine \\ e-mail: margozay@i.ua, orcid.org/0000-0003-4304-3644
}

\section{Summary}

The way of speaking in judicial discourse is determined by a strictly established «ritual» and the role of each participant in the process, which cannot be changed. Therefore, each litigant is recommended to have a different style of speech behavior or a certain communicative mode. A speech style generates certain patterns - ways of speaking in court. So, the article is devoted to the specific features of the communicative mode of mentative in judicial discourse, as well as the changing patterns of speech behaviour of participants in the judicial process. During the process of investigation, the following research methods have been used: linguistic observation and analysis as well as cognitive method, pragmatic analysis method, critical discourse analysis method. These methods have allowed us to establish the organization of the discursive space of judicial discourse in diachrony as well as transformation of linguistic means in the mentative. Moreover, this study sheds light on the change of patterns of speech behaviour in the mentative communicative mode. To sum up, compared to the other communicative modes in the judicial narrative, the communicative mode of mentative can be considered the least changed.

Keywords: notion of mode, diachrony, judicial discourse, discursive space, linguistic observation, pragmatic analysis method, critical discourse analysis method, cognitive method, speech pattern.

DOI: https://doi.org/10.23856/4519

\section{Introduction}

Judicial discourse, as a particular ritualised form of power to determine the truth, combines methods of observation, qualification, classification, punishment as a manifestation of force. Judicial discourse, due to the importance of the role of the judge in the judicial process, keeps drawing the attention of many researchers. Using his authority, the judge makes a distinction and puts forward a final judgment:

«... establishes over individuals a visibility through which one differentiates them and judges them» (Foucault, 1984: 197).

Whilst noting the increased interest of researchers in the concept of discursive space, we emphasise that the issue of «formation» of judicial discursive space created, «... as a result of parties' judicial negotiation» (Karyakin, 2009: 104), remains unresolved. This allows us to talk about the novelty of this study and its relevance. With this in mind, we consider it necessary to focus on a more detailed characterisation of judicial discursive space and patterns of speech behaviour in judicial discursive space, taking into account their changes, which is the aim of this research. In order to achieve the aforementioned objective, the following tasks need to be solved: formation;

- to establish patterns of speech behaviour in judicial discursive space and their trans-

- to describe the linguistic features of judicial discourse and their transformation. 
Troughout the process of investigation, the following research methods have been used: linguistic observation and analysis as well as cognitive method, pragmatic analysis method, critical discourse analysis method. These methods have allowed us to establish the organization of the discursive space of judicial discourse in diachrony as well as transformation of linguistic means in the mentative. Moreover, this study sheds light on the change of patterns of speech behaviour in the mentative communicative mode.

During a trial a judge creates a certain model of his discursive speech behaviour where he uses a coercive strategy expressed in specific linguistic means in order to achieve the optimal goal in the context of social interaction.

The discursive behaviour of the judge, as we believe, manifests itself in the mental communicative mode. Let us briefly elaborate on the characterisation of the concept.

\section{The notion of mentative communicative mode}

As a class of double-event discursive practices (Tyupa, 2020), linking qualitatively heterogeneous events - referential and communicative: the event of story and the event of storytelling, the narrative differs from the mentative, which can already be presented as «three-event», according to the terminology of A. B. Vdovichenko (Vdovichenko, 2016: 334). The mentative does not tell a story, but builds a discourse around the discourses outlined, interpreted by the narratives of the representative of the prosecution and the defense. It becomes therefore a meta-meta-communicative mental event, i.e. it is «...a thought about a thought, operating with versions, models, concepts, rather than things» (Vdovichenko, 2016: 333), a thought about a narrative. If a narrative sets a certain angle of view on an event, then the mentative builds its vision over the narrator's vision of the referential event, so «The referential content of mentative statements is not the event intrigue of life, but the procedural lawfulness of being» (Tyupa, 2020). Thus, the mental mode implies first of all an orientation towards the addressee, a change in the picture of the world in his mind. It is within the mental mode that coercive strategies and tactics can be implemented within the court, since speech activity in the mental mode is aimed at influencing in the first place and persuasion in the second, unlike in the narrative mode. The essence of mentative is «in its 'laying out', 'unfolding' for the Other - the super-experiential verification of meaning» (Tyupa, 2020). The judge acts as a bystander and makes a judgment based on the information presented in the provocative and inflective narratives in court. Thus, the mentative reinterprets already known information. At the same time, the information the judge receives is professionally elaborated by specialists. In this complex area of information, the judge has to navigate: to separate true facts from artificially transformed facts and make a decision. Furthermore, the function of the judge is also to exercise control over the whole process, positioning himself as a representative of the authority entrusted by the state with the power to administer justice. Finally, it must be mentioned that the judge also pronounces a valedictory speech to the jury, if they are present at the trial, in order for them to establish a verdict according to his instructions.

The discursive role of the judge in judicial discourse involves the following functions:

1) creating an authoritative image of the judge to organize an effective communicative process;

2) regulating the communication process in order to obtain full information from the agents of the process;

3) stimulating the communication process in the courtroom to obtain full information from the agents of the process; 
4) ensuring alternation, i.e. rotating the speaker and the listener to ensure the principle of adversarial communication; failure;

5) exercising message comprehension control and feedback to avoid communicative

6) providing own opinion to focus the jury's attention;

7) formulating the judgment in such a way as to eliminate the possibility of its further challenge.

\section{Organization of the discursive space of judicial discourse in diachrony}

Let us trace the organization of the discursive space of judicial discourse in diachrony.

In 2008, the civil case C - 07 - 1783 Theodore Ervin v. Cindy Young was heard. Let us consider how a judge's discursive activity is organized in the mentative mode. By the way, let us note and amplify an interesting statement by A.J. Greimas about discursive competence: «... discursive activity relies on some discursive skill, which is no different from the skill of a shoemaker, for example. In other words, we should assume the existence of narrative competence if we want to explain the production and understanding of specific discourse texts...» (Greimas, 1983: 503). Let us assume that there is also mentative competence, which is necessary to be able, as we have already said, to navigate through the information provided, to make a judgement and to organize the activities of the participants in the judicial process.

The Clerk: The Honorable Christopher C. Henderson presiding. (creating an authoritative image of the judge).

The Court: Please be seated. (regulating the communication process).

The Court: As far as strikes, is each Defendant requesting four? (stimulating the communication process).

Mr. Stephenson: Yeah.

Mr. Ford: Yes, Your Honor.

The Court: Are there cross claims? (stimulating the communication process).

Mr. Ford: Yes.

The Court: Okay. (exercising message comprehension control and feedback).

The Court: I am not gonna ask about it. (providing own opinion).

The Court: Defense? They 're basically the same questions - I mean. (ensuring alternation).

Mr. Ford: Yeah. (Theodore Ervin v. Cindy Young 2008).

Compare this trial with the famous Triangle Fire Trial 1911:

THE COURT: You may ask him a preliminary question. (creating an authoritative image of the judge, regulating the communication process).

MR. BOSTWICK: This is indictment No. 82,980.

THE COURT: I understand the application, made practically by both sides, is that the trial of this case be now adjourned until the first Monday in December. (stimulating the communication process).

MR. STEUER: That is correct.

MR. BOSTWICK: I don't understand that it is made on behalf of the People, if your Honor please.

THE COURT: Well, not opposed by the People. Application having been made by the defendant and not opposed by the People, in the case of the People against Isaac Harris and Max Blanck, the trial of it is now adjourned until the first Monday in December. (formulating the judgment). 
THE COURT: Whereas in this case it is part of the matter to be established that there was a requirement that a certain thing should be done, it is not improper to call to the attention of the jury, during summation, at least, that that thing was not done. I think, perhaps, in the opening it might be omitted. (providing own opinion).

THE COURT: I think your criticism is perhaps well founded, Mr. Steuer. You may outline the theory of the People's case, Mr. Bostwick. (ensuring alternation).

To summarise, the mentative discursive competence of judges and the question-and-answer form of judicial discourse organisation have not changed. What has changed is the selection of linguistic means and the selection of patterns of the judge's speech behaviour, both of which will be discussed in the following subsections.

\section{Transformation of linguistic means in the mentative}

General processes concerning judicial discourse, intimation, dialogisation and simplification have certainly affected judicial discourse as well.

For example, in the trial of Mahanoy Area School District v. B.L. of 23 January 2021. B.L., a student at Mahanoy Area High School (MAHS), went through a competitive selection process but did not make the high school cheerleading team, making it to the minor league team only. Over the weekend, she posted a picture of herself on Snapchat, a mobile messaging app with attached photos and videos, accompanying it with a profane caption. Several students who saw the photo with the caption came up to the coach and expressed concern that the photo and caption were inappropriate. The coaches decided that B.L.'s snapshot violated team and school rules that B.L. had agreed to before joining the team, so she was suspended from the junior varsity team for one year. B.L. sued the school, arguing that (1) her suspension from the team violated the First Amendment; (2) that the school and team rules were excessively vague and discriminatory; and (3) that the rules were unconstitutional. Let's analyze the language used by US Supreme Court justices.

The linguistic means of intimation include the pronoun «I», discursive markers expressing the attitude of the speaker to the message expressed; lexical means denoting misunderstanding, which become a kind of emotional signals that do not carry a particular meaningful load, but become an effective way to attract the attention of listeners by bright speech form; softened form of the imperative, for example.

JUSTICE BREYER: And if swearing off campus did, I mean, my goodness, every school in the country would be doing nothing but punishing. It didn't hurt others as far as I'm aware, as far as I can see in the record (Mahanoy Area School District v. B.L. 2021: 12).

JUSTICE ALITO: I have no idea what it means to target the school. Now let me give you an example to make this more concrete. All right. So now, the student says exactly the same thing and he adds, "Our classmate, Johnny Jones' brother, is one of those blankety-blank baby killers» (Mahanoy Area School District v. B.L. 2021: 15-16).

Linguistic markers of dialogisation include colloquial vocabulary and colloquial syntax (parcellation, elliptical sentences). This generally indicates a simplification of the judicial discourse, which is becoming more dynamic.

JUSTICE ALITO: Well, I - I just don't understand what that means in concrete terms. I'll give you another example (Mahanoy Area School District v. B.L. 2021: 17).

JUSTICE SOTOMAYOR: Ms. Blatt, the problem that I have with Tinker is that I'm not sure it's any clearer a rule than any of the others that you're criticizing. Let me start with just this case. Can you punish a student for cursing at home - (Mahanoy Area School District v. B.L. 2021: 19). 
JUSTICE SOTOMAYOR: - we could quibble with that, but my point is, I'm told by my law clerks, that among certain populations - a certain large percentage of the population, how much you curse is a badge of honor. That would surprise many parents (Mahanoy Area School District v. B.L. 2021: 20)

JUSTICE GORSUCH: Yeah. I-I - I'd like to pick up where Justice Kagan left off. II-I-I'm confused (Mahanoy Area School District v. B.L. 2021: 26).

JUSTICE GORSUCH: No, it's - I understand offense isn't enough. But, if

there's a major disruption, that - that is enough? (Mahanoy Area School District v. B.L. 2021: 27).

JUSTICE GORSUCH: Sure. But, if the school thinks that it's a-that-that the kids are reasonably reacting to offensive political and religious speech, then it - then it can address that issue? (Mahanoy Area School District v. B.L. 2021: 28).

JUSTICE THOMAS: Well, let me - let me ask - let me squeeze in one other question real quick.

Compare this trial with the famous Triangle Fire Trial 1911. Even in small text fragments, the formality of the linguistic means can be noted as a style-forming characteristic of this judicial discourse. For example, the modal verb may, which conveys the judge's formal permission or prohibition of certain actions; the modal verb will as a means of expressing the communicator's confidence in what has been said; the abundance of imperative forms; the passive voice; sentences with the introductory it:

THE COURT: You may open the case, Mr. Bostwick (Triangle Fire Trial 1911: 10).

THE COURT: Do not go into that. I may say that I have ruled, Mr. Steuer, and discussion is unnecessary. You may state the theory of the People's case, Mr. Bostwick (Triangle Fire Trial 1911: 14).

THE COURT: For the purpose of expediting the case, Mr. Steuer, it is conceivable that during the recess hour you and Mr. Bostwick may agree upon certain things which can be conceded, which would be merely matters of formal proof. (Triangle Fire Trial 1911: 15).

THE COURT: It will shorten the case (Triangle Fire Trial 1911: 20).

THE COURT: Read it (Triangle Fire Trial 1911: 22).

THE COURT: Proceed (Triangle Fire Trial 1911: 46).

THE COURT: You will probably find printed explanations on that diagram, and just study it, Mr. Juror. Just look at it without comment (Triangle Fire Trial 1911: 117).

THE COURT: Objection sustained; strike it out. I may say now, because it will save time, that where objection is taken I intend to confine the evidence very strictly to that which I conceive to have by possibility probative value upon what I conceive to be the discuss in the case. (Triangle Fire Trial 1911: 118).

THE COURT: I will allow it (Triangle Fire Trial 1911: 120).

Note also the presence of the pronoun we, which is used more frequently than the first person singular pronoun compared to the first trial:

THE COURT: We will designate it by something that is conceded here on the exhibit (Triangle Fire Trial 1911: 128).

THE COURT: Now we will proceed (Triangle Fire Trial 1911: 129).

Participial constructions and participle phrases also indicate the formality of the style:

THE COURT: The witness indicates with his finger the partition shown upon the diagram immediately adjoining the entrance door to the ninth floor from the Greene street side. Is that right? (Triangle Fire Trial 1911: 128). 
THE COURT: Being the partition running parallel with Washington place, it is at right angles with Greene Street and parallel with Washington place. Is that correct, Mr. Steuer, as a description? (Triangle Fire Trial 1911: 128).

Thus, a comparison of the factual material revealed that, compared to contemporary judge discourse, the judge discourse of the late nineteenth and early twentieth centuries makes active use of lexical, grammatical and stylistic means of manifesting formality.

\section{Change of patterns of speech behaviour in the mentative}

The main pattern of judge's discourse is the «I dominate» pattern of power, which is conditioned by the role of the judge - to administer justice by deciding civil and criminal cases. The judge, endowed with power, organizes and controls the actions of the participants in the process and assists them in exercising their rights and duties.

The following examples are taken from Case 14 - 185 Mata v. Lynch 2014 that was heard in the US Supreme Court and Triangle Fire Trial 1911.

So, only the judge has the right to ask questions in court of any participant:

JUSTICE KENNEDY: Can you explain why...? But why that is not a crime involving moral turpitude? ... why did the Fifth Circuit treat this, therefore, as a-as it requested review the sua sponte extension granted below? Why? Why would one that?

The judge may interrogate (1), clarify (2) and even interrupt any of the speakers (3):

(1) JUSTICE SOTOMAYOR: Now, I've-I'veforgotten, but is there a

circuit split on that third on the sua sponte review?(Mata v. Lynch 2014).

BY THE COURT: That is to say, the top of the surface of the table was two feet four and one-half inches above the floor level?

WITNESS: That's right, yes, sir (Triangle Fire Trial 1911).

(2) JUSTICE KAGAN: So on that assumption, that would, as I understand it, give the Fifth Circuit something new to think about in - in addressing this question; is that right? (Mata v. Lynch 2014).

BY THE COURT: What year? (Triangle Fire Trial 1911).

(3) MR. FLEMING: Now, because they have not ... 2014).

JUSTICE SCALIA: Which means there... there's no equitable tolling (Mata v. Lynch

BY THE COURT: So that the words "cutting tables" are not placed there from any actual knowledge of yours that cutting tables were there?

WITNESS: Excepting from the -

THE COURT: Yes or no?

THE WITNESS: (Continuing) No (Triangle Fire Trial 1911).

We note the following pattern as intrinsic to contemporary judicial discourse. In our view, it is due to the processes of dialogisation and intimidation which are thus reflected in the discourse. It is the pattern of «the judge is an ordinary person».

The judge as the dominant discursive person can joke in the courtroom, while the other participants are limited in doing so. Moreover, jokes on their part are considered inappropriate. Here are some examples from the case cited (the «judge is an ordinary person» pattern):

JUSTICE KENNEDY: You know the way to our hearts. (Laughter.)

JUSTICE KAGAN: He's definitely Justice Scalia. (Laughter.)

JUSTICE KAGAN: And we're not often confused. (Laughter.)

JUSTICE SCALIA: It's a good question, though. (Laughter.) (Mata v. Lynch 2014) 
All of the above is the basis for the assertion: the judge's speech manifests power - it is a domination pattern that is basic and immutable.

\section{Conclusions}

Compared to the other communicative modes in the judicial narrative, the communicative mode of mentative can be considered the least changed, as the question-answer form of its organization and the presence of the «I dominate» pattern due to the role of the judge as the authority to administer justice has not changed. The linguistic means used in the mental mode have changed: compared to the contemporary judicial discourse, the judicial discourse of the late nineteenth and early twentieth centuries makes active use of lexical, grammatical and stylistic means of manifesting formality.

\section{References}

Foucault, M. (1984). The Foucault Reader. New York: Pantheon Books. 389 p.

Greimas, A. J., Courte, J. (1983). Semiotika. Ob'yasnitelnyiy slovar teorii yazyika. Semiotika. Sost., vstup. st. i obsch. red. Yu.S. Stepanova [Semiotics. An Explanatory Dictionary of Language Theory. The Semiotics Explanatory Dictionary of the Theory of Language]. Moscow: Raduga. 550 p. [in Russian]

Karyakin, E. (2009). Teoreticheskie i prakticheskie problemyi formirovaniya istinyi po ugolovnomu delu $v$ sude pervoy instantsii [Theoretical and practical problems of forming the truth in a criminal case in the court of first instance]. Moscow: Yurlitinform. 296 p. [in Russian].

Tyupa, V. (2020). O granitsah narratologii [On the bounds of narratology].

https://netrefs.ru/v-i-tyupa-o-granicah-narratologii.html [in Russian]

Vdovichenko, A. (2016). O pandiskursivnosti verbalnyih faktov [On the pandiscursiveness of verbal facts]. Dialog so vremenem [Dialogue with Time]. Vol. 57. P. 332-341.

Mata v. Lynch Trial (2014). https://www.supremecourt.gov/oral_arguments/argument_transcripts/2014/14-185_6kg7.pdf

Triangle Fire Trial (1911). https://www.famous-trials.com/trianglefire 